\title{
Recent Progress in Preparation and Characterization of PBI Membranes for PEMFC
}

\author{
Li, Qingfeng; Precht Noyé, Pernille; Jensen, Jens Oluf; Pan, Chao; Bjerrum, Niels
}

Published in:

Meeting Abstracts - Electrochemical Society

Publication date:

2006

Document Version

Publisher's PDF, also known as Version of record

Link back to DTU Orbit

Citation (APA):

Li, Q., Precht Noyé, P., Jensen, J. O., Pan, C., \& Bjerrum, N. (2006). Recent Progress in Preparation and Characterization of PBI Membranes for PEMFC. In Meeting Abstracts - Electrochemical Society (pp. Abstract 412). The Electrochemical Society.

\section{General rights}

Copyright and moral rights for the publications made accessible in the public portal are retained by the authors and/or other copyright owners and it is a condition of accessing publications that users recognise and abide by the legal requirements associated with these rights.

- Users may download and print one copy of any publication from the public portal for the purpose of private study or research.

- You may not further distribute the material or use it for any profit-making activity or commercial gain

- You may freely distribute the URL identifying the publication in the public portal

If you believe that this document breaches copyright please contact us providing details, and we will remove access to the work immediately and investigate your claim. 
Abstract to the 210th ECS Meeting, Cancun, Mexico, October 29-November 3, 2006

Recent Progress in Preparation and Characterization of PBI Membranes for PEMFC

\section{Q. Li, P. Noyé, J. O. Jensen, C. Pan and N. J. Bjerrum}

Department of Chemistry

Technical University of Denmark

Building 207, DK-2800 Lyngby, Denmark

As a solid electrolyte membrane for high temperature proton exchange membrane fuel cells (PEMFCs), phosphoric acid doped polybenzimidazole (PBI) ${ }^{[1]}$ has received much attention recently ${ }^{[2-4]}$. The membrane possesses good mechanical properties ${ }^{[5]}$, high proton conductivity at low water activities ${ }^{[6,7]}$, and excellent thermal stability at temperatures up to $200^{\circ} \mathrm{C}$. Low methanol crossover rate and nearly zero water drag coefficient have also been reported.

Polybenzimidazoles (PBI) of different molecular weights have been synthesized in lab scale through different routes, both with and without catalysts. The polymers are characterized with respect to molecular weight and its distribution, solubility, thermal stability, etc. Membranes are prepared by solution casting and doped with acids.

When doped with phosphoric acid the membranes exhibit proton conductivity. The acid doping, however, results in high volume swelling. At an acid doping level of above 5 mole phosphoric acid per mole repeat unit of the polymer, a level necessary to obtain high enough proton conductivity for fuel cell applications, a volume swelling by about $120 \%$ was observed. The volume swelling means separation of the polymer backbones, which, in turn, reduces the mechanical strength and increases the $\mathrm{H}_{2}$ and $\mathrm{O}_{2}$ permeability of the membranes. ${ }^{[8]}$ By synthesizing high molecular weight polymers, the mechanical strength of the acid doped membranes can be significantly improved, as shown in Fig.1. Cross-linking by acid-base blends and introducing inorganic fillers have also been proved to be effective means to reduce the swelling and strengthen the membranes.

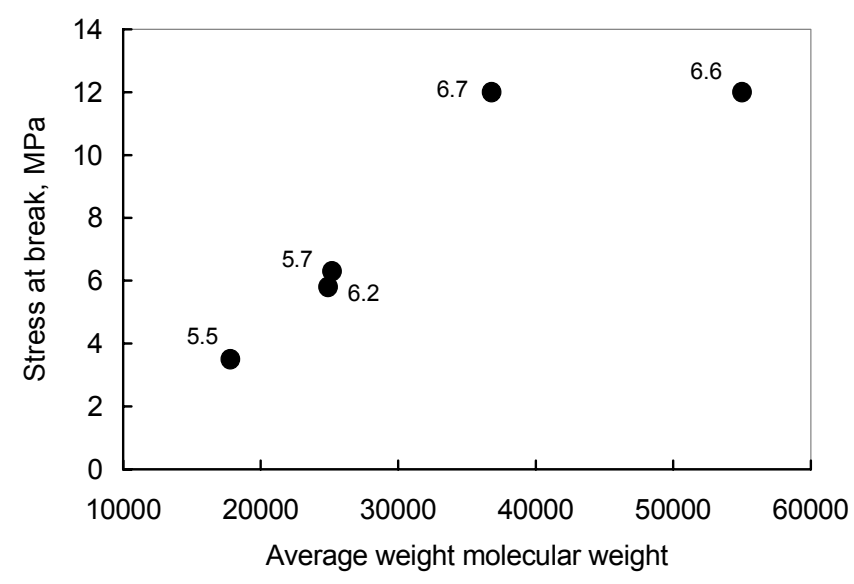

Fig.1. Engineering stress at break of acid doped PBI membranes as a function of molecular weight at $180^{\circ} \mathrm{C}$. The acid doping level is indicated in the figure.

Long tern durability has been a main concern in the development. Over 5000 hours of continuous operation has been demonstrated at $150^{\circ} \mathrm{C}$ with ambient hydrogen and oxygen. A daily startup-shutdown test operating with hydrogen and air has been cycled more than 600 times between room temperature and $150^{\circ} \mathrm{C}$ within a period of over 20,000 hours. $30 \%$ of the performance loss is observed, major part of which occurred during the first 50 cycles.

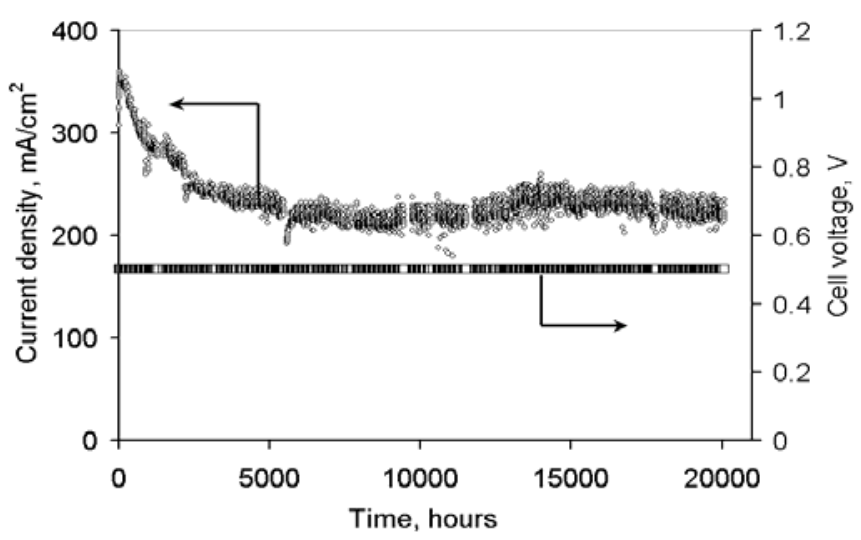

Fig.2. Lifetime test of a PBI cell with hydrogen and air under ambient pressure. The cell operates for about 7 hours every working day at $150^{\circ} \mathrm{C}$ and close down the rest of time during the overall time frame shown in the figure. The membrane was PBI doped with $5.6 \mathrm{~mol} \mathrm{H}_{3} \mathrm{PO}_{4}$. Platinum loading of each electrode was $0.61 \mathrm{mg} \mathrm{Pt} / \mathrm{cm}^{2}$.

Acknowledgement. This work has received financial support from the European Commission (Project no. SES6-CT-2004-502782).

\section{References}

[1] J. S. Wainright, J-T. Wang, D. Weng, R. F. Savinell, M. Litt, J. Electrochem. Soc. 142, L121 (1995).

[2] J. S.Wainright, M. H. Litt, R. F. Savinell, In Handbook of FuelCells, W.Vielstichm, A.Lamm, H.A. Gasteiger Eds.; John Wiley, Vol. 3, p 436, (2003).

[3] Q. Li, R. He, J. O. Jensen, J. Bjerrum, Chem. Mater. 15, 4896 (2003).

[4] Q. Li, R. He, J. O. Jensen, N. J. Bjerrum, Fuel Cells Fundam. Syst. 4, 147, (2004).

[5]. Litt, M.; Ameri, R.; Wang, Y.; Savinell, R.; Wainwright, J. Materials Research Soc., 548, 313 (1999).

[6]. Ma, Y-L.; Wainright, J. S.; Litt, M. H.; Savinell, R. F. J Electrochem Soc, 151, A8, (2004).

[7]. He, R.; Li, Q.; Xiao, G.; Bjerrum, N. J. J Membr Sci, 226, 169 (2003).

[8] R. He, Q. Li, A. Bach, J. O. Jensen, N.J. Bjerrum, J. Membr. Sci., 277, 38 (2006). 